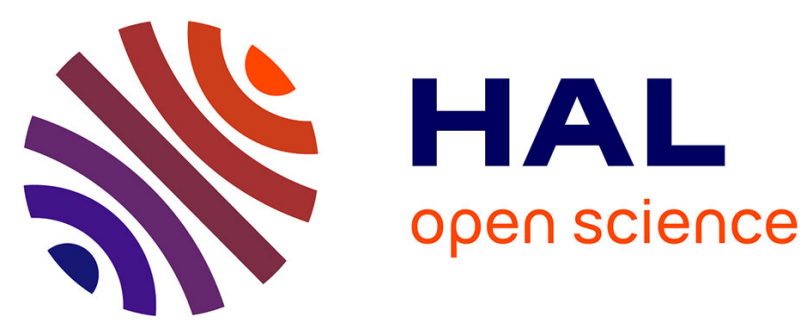

\title{
Short-term glucocorticoid treatment increases insulin secretion in islets derived from lean mice through multiple pathways, mechanisms
}

Malin Hult, Henrik Ortsäter, Gertrud Schuster, Florian Graedler, Johannes

Beckers, Jerzy Adamski, Alexander Ploner, Hans Jörnvall, Peter Bergsten,

Udo Oppermann

\section{To cite this version:}

Malin Hult, Henrik Ortsäter, Gertrud Schuster, Florian Graedler, Johannes Beckers, et al.. Shortterm glucocorticoid treatment increases insulin secretion in islets derived from lean mice through multiple pathways, mechanisms. Molecular and Cellular Endocrinology, 2009, 301 (1-2), pp.109. 10.1016/j.mce.2008.09.038 . hal-00532090

\section{HAL Id: hal-00532090 https://hal.science/hal-00532090}

Submitted on 4 Nov 2010

HAL is a multi-disciplinary open access archive for the deposit and dissemination of scientific research documents, whether they are published or not. The documents may come from teaching and research institutions in France or abroad, or from public or private research centers.
L'archive ouverte pluridisciplinaire HAL, est destinée au dépôt et à la diffusion de documents scientifiques de niveau recherche, publiés ou non, émanant des établissements d'enseignement et de recherche français ou étrangers, des laboratoires publics ou privés. 


\section{Accepted Manuscript}

Title: Short-term glucocorticoid treatment increases insulin secretion in islets derived from lean mice through multiple pathways, mechanisms

Authors: Malin Hult, Henrik Ortsäter, Gertrud Schuster, Florian Graedler, Johannes Beckers, Jerzy Adamski,

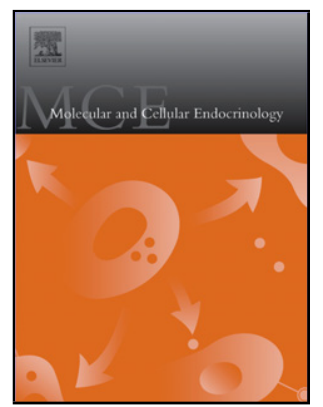
Alexander Ploner, Hans Jörnvall, Peter Bergsten, Udo Oppermann

PII: S0303-7207(08)00452-8

DOI: doi:10.1016/j.mce.2008.09.038

Reference: MCE 7011

To appear in: $\quad$ Molecular and Cellular Endocrinology

Received date: $\quad 31-8-2008$

Revised date: 30-9-2008

Accepted date: $\quad 30-9-2008$

Please cite this article as: Hult, M., Ortsäter, H., Schuster, G., Graedler, F., Beckers, J., Adamski, J., Ploner, A., Jörnvall, H., Bergsten, P., Oppermann, U., Short-term glucocorticoid treatment increases insulin secretion in islets derived from lean mice through multiple pathways, mechanisms, Molecular and Cellular Endocrinology (2008), doi:10.1016/j.mce.2008.09.038

This is a PDF file of an unedited manuscript that has been accepted for publication. As a service to our customers we are providing this early version of the manuscript. The manuscript will undergo copyediting, typesetting, and review of the resulting proof before it is published in its final form. Please note that during the production process errors may be discovered which could affect the content, and all legal disclaimers that apply to the journal pertain. 


\section{Short-term glucocorticoid treatment increases insulin secretion in islets derived from lean mice through multiple pathways and mechanisms}

Malin Hult ${ }^{1+}$, Henrik Ortsäter ${ }^{2+}$, Gertrud Schuster ${ }^{3}$, Florian Graedler ${ }^{4}$, Johannes

Beckers $^{4}$, Jerzy Adamski ${ }^{4,8}$, Alexander Ploner ${ }^{5}$, Hans Jörnvall ${ }^{1}$, Peter Bergsten ${ }^{2}$ and Udo Oppermann ${ }^{1,6,7^{*}}$

${ }^{1}$ Department of Medical Biochemistry and Biophysics, Karolinska Institutet, SE-171 77 Stockholm, Sweden

${ }^{2}$ Department of Medical Cell Biology, Uppsala University, Uppsala, Sweden

${ }^{3}$ Department of Medical Nutrition, NOVUM, Karolinska Institutet, SE-141 86

Huddinge, Sweden

${ }^{4}$ Helmholtz Zentrum München, German Research Center for Environmental Health, Institute of Experimental Genetics, Genome Analysis Center, 85764 Neuherberg,

Germany

${ }^{5}$ Department of Epidemiology and Statistics, Karolinska Institutet, Sweden

${ }^{6}$ present address: Structural Genomics Consortium, University of Oxford, OX3 7DQ, $U K$

${ }^{7}$ Botnar Research Centre, Oxford Biomedical Research Unit, Oxford, OX3 7LD, UK

${ }^{8}$ Technische Universität München, Center of Life and Food Sciences Weihenstephan, Institute of Experimental Genetics, 85354 Freising, Germany

${ }^{+}$These authors contributed equally to the work

* Author for correspondence

E-mail: udo.oppermann@sgc.ox.ac.uk 


\section{SUMMARY}

Chronic exposure to elevated levels of glucocorticoids leads to metabolic dysfunctions with hyperglycemia and insulin resistance. Long-term treatment with glucocorticoids induces severe impairment of glucose-stimulated insulin secretion. We analyzed the effects of short-, and medium- term (2-120 hrs) treatment with 50-200 nM glucocorticoids on primary pancreatic islet cultures derived from lean C57BL/6J mice. In contrast to animal models of insulin resistance, $\beta$-cells from lean mice respond with an increased glucose-stimulated insulin secretion, with a peak effect around 18-24 hrs of treatment. Analyses of the insulin secretion response reveal that early and late phase responses are dissociated upon glucocorticoid treatment. Whereas late phase responses return to basal levels after long treatment, early phase responses remain increased over several days. Increased insulin secretion is also obtained by incubation with the inactive glucocorticoid dehydrocorticosterone, pointing to an important role of the enzyme $11 \beta$-hydroxysteroid dehydrogenase type 1 in mediating glucocorticoid effects in $\beta$-cells.

Transcript profiling revealed differential regulation of genes involved in mediation of signal transduction, insulin secretion, stress and inflammatory responses. The results show that short- to medium-term glucocorticoid treatment of pancreatic islets derived from lean mice leads to an increased insulin release and may constitute an important parameter in changing towards a pro-diabetic phenotype. 
Running Title: Glucocorticoid mediated changes in pancreatic islet function

Key words: insulin resistance, glucose stimulated insulin secretion, glucocorticoid, inflammation, 11beta-hydroxysteroid dehydrogenase

Abbreviations: 11 $\beta$-HSD: 11 $\beta$-hydroxysteroid dehydrogenase GR: glucocorticoid receptor; GPCR: G-protein coupled receptor; GC: glucocorticoid; GSIS: glucosestimulated insulin secretion 


\section{INTRODUCTION}

The $\beta$-cells of the pancreatic islets of Langerhans are an essential component in vertebrate physiology by their unique ability to synthesize and release insulin, the vital hormone regulating maintenance of glucose homeostasis. Insulin synthesis, intracellular storage and secretion are tightly controlled through multiple mechanisms including complex sets of stimuli such as nutrients, neural and humoral factors (Lang, 1999). Glucose-stimulated insulin secretion is mediated through glucose metabolism within the $\beta$-cell, providing ATP which in turn triggers regulation of ATP-dependent potassium channels, membrane depolarization and opening of voltage dependent $\mathrm{Ca}^{2+}$ channels (reviewed in (Ashcroft et al., 1994, Berggren and Larsson, 1994). This cascade leads to release of insulin from intracellular storage vesicles, produced in the secretory pathway. Whereas this stimulus-secretion coupling takes seconds or minutes, longer term adaptation of the $\beta$-cell to nutrient states includes transcriptional responses (Itoh and Okamoto, 1980, Leibiger et al., 1998). Derangement of any of these processes is linked to reduced insulin production and secretion, and constitutes an important factor in the development of diabetes mellitus (Itoh and Okamoto, 1980, Lang, 1999, Leibiger et al., 1998).

Glucocorticoid hormones regulate essential physiological functions in mammals by binding to nuclear receptors controlling gene transcription. An important determinant in glucocorticoid physiology is a system of enzymes involved in pre-receptor control of active hormone ligand (Tomlinson and Stewart, 2007, Walker and Seckl, 2003). The tissue-specific metabolic activation of glucocorticoid precursors (cortisone in humans, dehydrocorticosterone in rodents) to the active ligand (cortisol, corticosterone) is carried out by type $111 \beta$-hydroxysteroid dehydrogenase (11ßHSD1), which acts as an NADPH-dependent reductase (Oppermann et al., 1997, Oppermann, 2006). The reverse reaction is carried out by a $\mathrm{NAD}^{+}$-dependent type 2 $11 \beta$-HSD (11 -HSD2), predominantly localized in mineralocorticoid receptor (MR) positive cells. Hyperglycemia, insulin resistance and hyperinsulinemia result from excess of glucocorticoids (Lenzen and Bailey, 1984). These conditions are believed to be the result of interactions between the different organs involved in glucose homeostasis, i.e. liver, skeletal muscle, adipose tissue and the islets of Langerhans. 
Direct effects of glucocorticoids on $\beta$-cells have been reported and show different results. Whereas increased insulin release was found in long-term islet culture (3 weeks) with hydrocortisone or dexamethasone (Brunstedt and Nielsen, 1981, Karlsson et al., 2001, Kawai and Kuzuya, 1974, Kawai and Kuzuya, 1977) glucocorticoid mediated suppression of insulin secretion is reported from islets derived from normal animals (Koizumi and Yada, 2008, Lambillotte et al., 1997) or animal models of type 2 diabetes mellitus, e.g. ob/ob mice (Delaunay et al., 1997, Khan et al., 1992). We have described a decrease in insulin secretion in islets from $o b / o b$ mice by glucocorticoid activation through $11 \beta$-HSD1, and reversal of this effect by use of $11 \beta$ HSD1 inhibitors (Davani et al., 2000, Ortsater et al., 2005). Importantly, animals overexpressing the glucocorticoid receptor in $\beta$-cells ultimately develop manifest diabetes at 12-15 months of age (Davani et al., 2004). Taken together, these data point to a complex response of $\beta$-cells to glucocorticoids with regard to insulin secretion. The present study addresses the effects of glucocorticoids during short-term treatment of islets derived from lean mice. We describe how corticosterone treatment under these conditions results in increased insulin secretion, and we analyse by microarray analysis the underlying transcriptional changes in pancreatic islets.

\section{EXPERIMENTAL}

Chemicals: Analytical grade reagents and MilliQ water were used. Collagenase, HEPES and bovine serum albumin (fraction V) were from Boehringer Mannheim GmbH (Mannheim, Germany), RPMI 1640 culture medium and fetal bovine serum were from Invitrogen (Carlsbad, CA). Mifepristone (RU486) and steroids were from Sigma (St. Louis, MO), radioactive corticosterone (specific activity $70 \mathrm{Ci} / \mathrm{mmol}$ ) was from NEN-Dupont, labeled dehydrocorticosterone was synthesized using recombinant $11 \beta$-HSD1, extracted, and purified by thin-layer chromatography. The rat insulin standard was from Novo Nordisk (Bagsvaerd, Denmark). Guinea pig anti-mouse insulin antibodies were produced as described [20]. IgG-certified 96-well microtiter plates were purchased from Nunc (Roskilde, Denmark).

Islet preparation and culture: Male 3-5 months old C57BL/6J mice (B\&K, Sollentuna, Sweden) were used as islet source. Pancreatic islets were isolated by collagenase digestion, and cultured for 2-120 hrs in RPMI 1640 culture medium supplemented with $5.5 \mathrm{mM}$ glucose, $10 \%$ fetal bovine serum and 0 or $200 \mathrm{nM}$ 
corticosterone or $50 \mathrm{nM}$ dehydrocorticosterone. For culture times longer than $48 \mathrm{hrs,}$ culture medium was changed every $48 \mathrm{hrs}$. A group of corticosterone-treated islets (18 hrs treatment) were treated with $1 \mu \mathrm{M}$ RU486. Corticosterone was dissolved in 95\% ethanol and diluted in culture medium giving a final ethanol concentration of $0.1 \%$ (v/v), whereas RU486 was dissolved in DMSO and diluted in culture medium giving a final DMSO concentration of $0.1 \%(\mathrm{v} / \mathrm{v})$. The same concentrations of ethanol and DMSO were used in the control experiments. The procedures involving animals were approved by the local animal ethical committee.

Measurement of insulin release: After cultivation, individual islets were perifused and insulin secretion was determined by ELISA as previously described (Bergsten and Hellman, 1993, Ortsater et al., 2005).In short, one individual islet per experiment was placed in a $10-\mu 1$ chamber, made of Teflon-tubing and perifused at a rate of 150 to $160 \mu \mathrm{L}$ per min. The perifusion medium was supplemented with $1 \mathrm{mg} / \mathrm{mL}$ albumin and contained (in $\mathrm{mM}$ ): $\mathrm{NaCl} 125, \mathrm{KCl} 5.9, \mathrm{MgCl}_{2} 1.2, \mathrm{CaCl}_{2} 1.28, \mathrm{HEPES} 25$ and glucose 3, titrated to $\mathrm{pH} 7.4$ with $\mathrm{NaOH}$ and thermostated at $37{ }^{\circ} \mathrm{C}$. After a 60 -min equilibration period at $3 \mathrm{mM}$ glucose, samples were collected every $5 \mathrm{~min}$ for $15 \mathrm{~min}$, before elevating the glucose concentration to $11 \mathrm{mM}$. To ensure good time resolution of the initial secretory response, samples were taken every 2 min during the first 10 min at $11 \mathrm{mM}$ glucose. Subsequently, samples were collected every $5 \mathrm{~min}$ for an additional $20 \mathrm{~min}$. At the end of the experiments, islet functionality was verified by lowering the glucose concentration of the perifusion medium to $3 \mathrm{mM}$ to test the reversibility of GSIS. Second, the insulin secretory capacity was confirmed by depolarization with high potassium ion concentration $(30 \mathrm{mM})$. Experiments where GSIS was not reversible or potassium depolarization failed to induce insulin secretion were excluded from the calculations. The perifusate samples were stored at $-20{ }^{\circ} \mathrm{C}$ until assayed for insulin. Insulin in the perifusate was assayed by a competitive enzyme-linked immunosorbant assay (ELISA) with the anti-insulin antibodies immobilized directly to the solid phase. The rate of insulin release was normalized to islet dry weight after freeze-drying and weighing the islets on a quartz fiber balance. Differences in insulin secretion were evaluated within each experiment group with an ANOVA for repeated measurements and between groups with factorial ANOVA and Fischer's posthoc test. P-values lower than 0.05 were considered significant. Values were expressed as means \pm standard error of the mean (SEM). 
Analysis of glucocorticoid-induced transcriptional changes in islets: Pancreatic islets obtained from C57BL/6J mice were isolated as described above in 2 biological replicates, each replicate consisted of islets pooled from 6-7 mice. Each biological replicate was divided in two halves, and either treated with $200 \mathrm{nM}$ corticosterone or the appropriate volume of solvent overnight at $37^{\circ} \mathrm{C}$. Aliquots of the samples were analyzed for insulin secretion, as detailed above. Total RNA was extracted from the islets using QIAshredder Homogenizer (Qiagen) in combination with RNeasy Mini Kit (QIAgen) and on column DNAse I treatment with the RNase-Free DNAse Set (QIAgen) according to the manufacturer's instructions. An amount of $25 \mu \mathrm{g}$ total RNA was obtained for each sample. $1 \mu \mathrm{g}$ of each of the four samples were loaded onto $1.2 \%$ agarose gels stained with ethidium bromide, to investigate the quality of the isolated total RNA. The four pooled RNA samples described above were hybridized on microarray chips as detailed below. The experimental microarray design setup was to hybridize untreated and corresponding corticosterone-treated samples in 2 dye-swap pairs onto the slides. There were 5 slides in total, including an additional technical replicate.

Microarrays were produced using a non-redundant mouse cDNA clone library purchased from Lion Biosciences, containing nearly 21,000 sequence-verified and size-matched cDNA fragments, mainly from the 3' untranslated region. cDNA inserts were PCR-amplified with universal amino-linked M13 primers, purified on Millipore MultiScreen membranes according to a TIGR institute procedure (Hedge et al., 2000). PCR products were spotted onto silylated glass slides (Cell Associates), using a Microgrid Pro spotting robot (Biorobotics) as described (Drobyshev et al., 2003). Amino-linked cDNA products were covalently bound to free aldehyde groups attached to the surface.

Total RNA was transcribed into cDNA and labelled with cyanine 3/5 fluorophores. Labelled cDNA products resulting from $5 \mu \mathrm{g}$ total RNA of treated and untreated cells, were combined and hybridized overnight to the arrays at $42^{\circ} \mathrm{C}$ in a buffer containing $50 \%$ formamide, 6X SSC, $0.5 \%$ SDS and 5\% Denhardt's solution. Hybridized slides went through a series of washes with increasing stringency and were subsequently analyzed with an Axon 4000 scanner. Raw data were acquired and extracted using the GenePix software, version 4.0 (Axon). 
Background-corrected intensity ratios were normalized using print tip-specific LOESS curves (Yang et al., 2002) and spots were also scale normalized across arrays. Analysis was performed following the least square/empirical Bayes method, using the package LIMMA 1.0.8 (LIMMA: Linear Models for Microarray Data. http://bioinf.wehi.edu.au/limma/) for the open-source statistics package R 1.7.1 (R: R development Core Team, Vienna, Austria, 2003. http://www.R-project.org). A table of the 100 top-ranked differentially expressed genes was obtained, based on the pvalues of the t-statistics of the contrasts. Spots flagged by the scanning software for quality considerations were down-weighted to $10 \%$ in the print tip normalization and computation of t-statistics. P-values were adjusted for multiple comparisons by false discovery rate (FDR) (Benjamini et al., 2001).

Quantitative real time PCR (RTQ-PCR): cDNA was prepared as previously described using $1 \mu \mathrm{g}$ total RNA (Stulnig et al., 2002, Stulnig et al., 2002). Primer sequences, designed using PRIMER EXPRESS software (PE Applied Biosystems), are listed in Table 1. The PCR reaction mixture contained, in a final volume of $25 \mu 1$, $1 \%$ of the cDNA, $12.5 \mu 1$ of 2xSYBRgreen Universal Mastermix (PE Applied Biosystems, Foster City, CA), and corresponding primers. RTQ-PCR was performed in triplicates by using an ABI PRISM 7700 Sequence Detection Systems instrument and software (PE Applied Biosystems). RNA samples were normalized for comparison by determination of $18 \mathrm{~S}$ rRNA levels.

$11 \beta$-HSD1 dehydrocorticosterone reductase activity in islets of Langerhans. The dehydrocorticosterone reductase activity of the isolated islets was investigated with islets treated overnight at $37^{\circ} \mathrm{C}$ in $50 \mathrm{nM}$ dehydrocorticosterone, $200 \mathrm{CPM}{ }^{3} \mathrm{H}-$ dehydrocorticosterone $+/-5 \mu \mathrm{M}$ carbenoxolone. Additional samples without islets were used as negative controls. Each point was run as triplicate samples, and each sample contained approximately 40 islets. Islets were grown in 6-well plates at $37^{\circ} \mathrm{C}$ overnight in $2 \mathrm{ml}$ culture medium. Steroids were extracted from the medium (OASIS HLB extraction columns, Waters), eluted in $2 \mathrm{ml} \mathrm{MeOH}$, evaporated under a nitrogen stream and reconstituted in $100 \mu \mathrm{MeOH}$. The conversion of steroid was evaluated by reverse-phase HPLC separation, UV and radioactivity detection on a $\mathrm{C}_{18}$ column in $30 \%$ acetonitrile, $0.1 \%$ ammonium acetate, $\mathrm{pH} 7.0$, at a flow rate of $1 \mathrm{ml} / \mathrm{min}$. 


\section{RESULTS}

Insulin secretion. Pancreatic islets from lean C57BL/6J mice were isolated and cultured for various time periods ranging from 2-120 hrs. Islets were left untreated or treated with $200 \mathrm{nM}$ corticosterone, with or without the glucocorticoid receptor antagonist RU486, to investigate the effects of glucocorticoid on glucose-stimulated insulin secretion (GSIS) (Fig 1A and 1B). To dissect the insulin secretion response phases upon glucose stimulation, perifusate aliquots were taken at different time points and analyzed for insulin content. Figure 1A shows a representative pattern from islets cultured for $18 \mathrm{hrs}$. The average insulin secretory rate in untreated islets was $10 \pm 2 \mathrm{pmol} \cdot \mathrm{g}^{-1} \cdot \mathrm{s}^{-1}$ at $3 \mathrm{mM}$ glucose. Increasing the glucose concentration to $11 \mathrm{mM}$ caused a pronounced early phase of insulin secretion. During the time period 2-6 min post glucose elevation average insulin secretory rate was $195 \pm 42 \mathrm{pmol} \cdot \mathrm{g}^{-1} \cdot \mathrm{s}^{-1}(\mathrm{p}<0.05$ compared to $3 \mathrm{mM}$ glucose). During the time period 10-25 min post glucose elevation, the late phase of insulin secretion, the average secretory rate in untreated islets was $72 \pm 17 \mathrm{pmol} \cdot \mathrm{g}^{-1} \cdot \mathrm{s}^{-1}$ ( $\mathrm{p}<0.05$ compared to $3 \mathrm{mM}$ glucose). Treating islets with $200 \mathrm{nM}$ corticosterone did not affect the basal insulin secretory rate but enhanced both the early and the late phases of GSIS 2- and 3-fold, respectively $(\mathrm{p}<0.05)$. Including RU486 together with corticosterone during culture reduced the corticosterone-induced enhancement of GSIS $(\mathrm{p}<0.05)$ for the early phase and blocked completely the late phase effects. Indeed, such islets had secretory rates comparable with those from untreated islets (Fig. 1A). Basal and GSIS were further investigated as a function of duration of glucocorticoid exposure (Fig. 1B). Whereas no significant changes in either basal or any of the two GSIS phases were observed after 2 hrs incubation with the steroid, distinct differences were observed after longer treatment. Basal insulin secretion was not affected by corticosterone in any of the time points investigated. However, corticosterone induced a significant rise in early phase response after $18 \mathrm{hrs,}$ which remained elevated even after $120 \mathrm{hrs}$ of treatment. The late phase was elevated in islets treated for 18 and $24 \mathrm{hrs}$ but declined towards basal levels after prolonged treatment.

11 $\beta$-HSD1 dehydrocorticosterone reductase activity and GSIS. Islets were treated with $50 \mathrm{nM}$ of the glucocorticoid precursor dehydrocorticosterone to investigate its effects on insulin release. The effects resulted in, similar to corticosterone treatment, a 
3.5-fold increase of GSIS in comparison to the untreated islets (Fig. 2A), demonstrating glucocorticoid activation by 11 -HSD1 in islets derived from lean mice. Pancreatic islets were isolated and cultured overnight with $50 \mathrm{nM}$ dehydrocorticosterone, with or without $5 \mu \mathrm{M}$ carbenoxolone to investigate the $11 \beta$ HSD1 reductase activity. The dehydrocorticosterone (DHC) reductase activity in the islets was estimated to $1.4 \pm 0.8 \mathrm{pmol} / 30 \mathrm{~min} /$ islet (Fig. 2B). A complete inhibition of the activity was obtained upon co-culturing with the 11ß-HSD antagonist carbenoxolone.

Microarray data analysis. Mouse microarray chips containing nearly 21,000 nonredundant cDNA clones were used for the study of pancreatic islets in response to glucocorticoid treatment of perifused islets derived from lean mice. The 100 most differentially expressed genes upon corticosterone treatment were grouped according to function, as shown in Table 2. The majority of the 100 genes revealed functions in signal transduction (15 genes), stress response (25 genes), metabolism (13 genes), or were unassigned (21 genes). Within the 100-top-result list, genes were selected from the various functional classes for RTQ-PCR (cf Table 1). A scatter plot (Fig. 3) of pvalue vs. estimated fold change displays all genes on the chip, discriminating the ones of $\mathrm{p}<0.05$ and $>2$-fold change, including the genes that were quantified by RT-PCR. The four original RNA samples were investigated by RTQ-PCR (Fig 4) using target primer concentrations of $100 \mathrm{nM}$. Of 11 genes selected for RTQ-PCR, 2 were chosen on biological basis of glucocorticoid regulations and responses, although they did not appear among the 100-top list (Pdx1, 11 $\beta$-HSD1). Differential expression of 8 out of the 9 remaining genes selected from the 100-top list could be qualitatively confirmed by RTQ-PCR. 11 $\beta$-HSD1 was found to be upregulated by the glucocorticoid treatment, whereas Pdx1 was downregulated. In general, the RTQ-PCR results strengthen the results of the microarray data, showing a clear response to the glucocorticoid treatment with particular genes including Itmap1, Fabp4, Rgs2, Lcn2 and RNase4, being differentially expressed.

\section{DISCUSSION}

This study highlights two important effects of glucocorticoid hormones (GCs) on $\beta$ cell function. The first regards their function as a modulator of GSIS and the second 
their ability to provoke a transcriptional response. GCs are stress hormones regulating a multitude of important effects in metabolism and inflammation. GCs provoke hyperglycemia and hyperinsulinemia, effects thought to arise from increased hepatic gluconeogenesis and decreased peripheral insulin sensitivity. In addition, direct effects on $\beta$-cells are reported, with partially contradictory results on glucose-stimulated insulin secretion. Whereas long-term increased GC sensitivity leads to decreased ability of the $\beta$-cell to respond to glucose by insulin secretion, probably through upregulation of $\alpha_{2}$-adenergic receptors and G-protein coupled receptor (GPCR) signaling (Davani et al., 2004), short- to medium term GC effects on the $\beta$-cells are not that clear-cut. Most reports show decreased insulin responsiveness upon GC treatment in various animal models (Davani et al., 2004, Delaunay et al., 1997, Jeong et al., 2001, Koizumi and Yada, 2008, Swali et al., 2008) including in islets derived from the hyperglucocorticoidemic ob/ob mouse model (Davani et al., 2000). In contrast to our results with $o b / o b$ islets (Davani et al., 2000, Ortsater et al., 2005), we now show that islets treated over different time intervals and derived from lean C57BL/6J mice, respond with a significant increase in insulin secretion upon GC treatment. This is in concordance with other reports demonstrating increase in insulin secretion upon GC treatment (Karlsson et al., 2001, Kawai and Kuzuya, 1974, Kawai and Kuzuya, 1977), the latter study showing similar responses (3-4 fold increase in GSIS) to GC treatment as in our experiments. These effects are mediated through the glucocorticoid receptor (GR), as demonstrated by decrease in insulin secretion to control levels using the receptor antagonist RU486 (Fig 1A). Furthermore, we demonstrate that different phases in GSIS responses are differentially affected by glucorticoids, indicating distinct glucocorticoid regulated components in glucose response pathways.

An important determinant of GC signaling is amplification of the steroid hormone signal by intracellular activation of precursor 11-oxoglucocorticoids (cortisone in humans, dehydrocorticosterone, DHC, in rodents), activated through 11ß-HSD1. We here show (Fig 2) by substrate conversion and carbenoxolone inhibition experiments that $11 \beta$-HSD1 is present in islets from lean mice. Importantly, islets receiving the DHC precursor respond in a manner equivalent to that of corticosterone-treated cells, by an increased response in GSIS (Fig 2). Differential expression of 11ß-HSD1 in 
islets appears to be a distinguishing feature, as observed earlier in experiments using lean and diabetic ZDF rats (Duplomb et al., 2004). In this study, PPAR $\gamma$ agonist treatment reduced expression levels of $11 \beta$-HSD1 in islets, as noted earlier in adipocytes or liver (Berger et al., 2001, Stulnig et al., 2002). Assuming an essential role of $11 \beta-H S D 1$ in GC signal transmission in islets, we note that the effects of PPAR $\gamma$ treatment of control and non-steroid induced, diabetic patients (Willi et al., 2002, Willi et al., 2002), resulting in increased insulin secretion, are in agreement with insulin secretion data obtained in the present and our previous studies (Davani et al., 2000, Ortsater et al., 2005). A recent study (Swali et al., 2008) shows that $11 \beta$-HSD1 is colocalized to cells expressing glucagon and not found in $\beta$-cells, thus a paracrine effect of glucocorticoid activation on insulin secretion is apparent.

We conducted microarray analysis to investigate glucocorticoid regulated genes potentially involved in insulin secretion. We selected a time point of $18 \mathrm{hrs}$ steroid incubation, showing a response to the treatment, with several signal transduction pathways affected. We demonstrate that several genes are upregulated. In this manner, increased expression of Fabp4 is a hallmark of metabolic dysregulation. Fkbp5 regulates GC response (Davies et al., 2002) by binding to the GC receptor and is likely to cause GC resistance in response to high doses of GCs (Denny et al., 2000), and upregulation of Rgs2 will lead to a decreased response in glucose-dependent insulinotropic polypeptide (GIP) mediated insulin secretion (Tseng and Zhang, 2000). However, several distinct components are upregulated and lead to enhanced insulin secretion. These genes comprise ion channels (amiloride sensitive cation channel, leading through depolarization to $\mathrm{Ca}^{2+}$ release), elements of GPCR signaling (Grb10, interaction with PI3 kinase) (Deng et al., 2003), protein and inositol phosphate kinases (inositol trisphosphate 3 kinase), metabolic enzymes (lipoprotein lipase, allowing uptake of free fatty acids) and cytoskeleton or vesicle components (chromogranin B). Taken together, this part of the study shows that GCs regulate a distinct set of genes involved in enhanced insulin secretion.

Surprisingly we found a large amount of differentially regulated genes mediating stress responses or inflammatory signals. Besides acute phase proteins (e.g. lipocalin, trefoil factor 2, serum amyloid 3), we found a considerable number of extracellular proteases, inhibitors, heat shock proteins and chaperones involved in tissue 
remodelling, or stress reponse enzymes such as glutamyl cysteine ligase. It will be of future interest to compare the expression pattern changes observed in this work with a recent study conducted on islets derived from spontaneously diabetic GK rats (Ghanaat-Pour et al., 2007).

Furthermore, the detection of the proinflammatory cytokine IL-1 $\beta$ in primary islet culture confirms an earlier report on expression of this mediator (Johansson et al., 2003). Downregulation of IL1 $\beta$ by glucocorticoids explains the decreased levels of Serpina12 observed in the microarray experiments, since this and other protease components are regulated through inflammatory signals and further highlights the anti-inflammatory properties of glucocorticoids.

Taken together, this study presents clear evidence that in the early phase of GC exposure, $\beta$-cells of primary islet cultures from lean mice act by increased insulin secretion, displaying a distinct profile of stress regulation. This situation possibly primes the cells for a switch in GC response, leading to glucose insensitivity and decrease in insulin secretion.

\section{ACKNOWLEDGEMENTS}

This study was supported by grants from the NovoNordisk Foundation, the Swedish Medical Research Council (72x-14019), the European Foundation for the Study of Diabetes, the Swedish Foundation for Strategic Research, the Swedish Diabetes Association, the Swedish Medical Association, the Swedish Foundation for International Cooperation in Research and Higher Education the Swedish Society for Medical Research, Göran Gustafsson Foundation, Magnus Bergvall Foundation, Filip Lundbergs Foundation, Family Ernfors Fund and Syskonen Svenssons Fund and Karolinska Institutet. Expert technical assistance by Monica Lindh is gratefully acknowledged.

\section{REFERENCES}

Ashcroft, F.M., Proks, P., Smith, P.A., Ammala, C., Bokvist, K. and Rorsman, P. (1994) Stimulus-secretion coupling in pancreatic beta cells. J Cell Biochem 55 Suppl, 54-65.

Benjamini, Y., Drai, D., Elmer, G., Kafkafi, N. and Golani, I. (2001) Controlling the false discovery rate in behavior genetics research. Behav Brain Res 125, 27984. 
Berger, J., Tanen, M., Elbrecht, A., Hermanowski-Vosatka, A., Moller, D.E., Wright, S.D. and Thieringer, R. (2001) Peroxisome proliferator-activated receptorgamma ligands inhibit adipocyte 11 beta -hydroxysteroid dehydrogenase type 1 expression and activity. J Biol Chem 276, 12629-35.

Berggren, P.O. and Larsson, O. (1994) Ca2+ and pancreatic B-cell function. Biochem Soc Trans 22, 12-8.

Bergsten, P. and Hellman, B. (1993) Glucose-induced amplitude regulation of pulsatile insulin secretion from individual pancreatic islets. Diabetes 42,670 4.

Brunstedt, J. and Nielsen, J.H. (1981) Direct long-term effect of hydrocortisone on insulin and glucagon release from mouse pancreatic islets in tissue culture. Acta Endocrinol (Copenh) 96, 498-504.

Davani, B., Khan, A., Hult, M., Martensson, E., Okret, S., Efendic, S., Jornvall, H. and Oppermann, U.C. (2000) Type 111 beta -hydroxysteroid dehydrogenase mediates glucocorticoid activation and insulin release in pancreatic islets. $\mathbf{J}$ Biol Chem 275, 34841-4.

Davani, B., Portwood, N., Bryzgalova, G., Reimer, M.K., Heiden, T., Ostenson, C.G., Okret, S., Ahren, B., Efendic, S. and Khan, A. (2004) Aged Transgenic Mice With Increased Glucocorticoid Sensitivity in Pancreatic beta-Cells Develop Diabetes. Diabetes 53 Suppl 1, S51-S59.

Davies, T.H., Ning, Y.M. and Sanchez, E.R. (2002) A new first step in activation of steroid receptors: hormone-induced switching of FKBP51 and FKBP52 immunophilins. J Biol Chem 277, 4597-600.

Delaunay, F., Khan, A., Cintra, A., Davani, B., Ling, Z.C., Andersson, A., Ostenson, C.G., Gustafsson, J., Efendic, S. and Okret, S. (1997) Pancreatic beta cells are important targets for the diabetogenic effects of glucocorticoids. J Clin Invest 100, 2094-8.

Deng, Y., Bhattacharya, S., Swamy, O.R., Tandon, R., Wang, Y., Janda, R. and Riedel, H. (2003) Growth factor receptor-binding protein 10 (Grb10) as a partner of phosphatidylinositol 3-kinase in metabolic insulin action. J Biol Chem 278, 39311-22.

Denny, W.B., Valentine, D.L., Reynolds, P.D., Smith, D.F. and Scammell, J.G. (2000) Squirrel monkey immunophilin FKBP51 is a potent inhibitor of glucocorticoid receptor binding. Endocrinology 141, 4107-13.

Drobyshev, A.L., Machka, C., Horsch, M., Seltmann, M., Liebscher, V., Hrabe de Angelis, M. and Beckers, J. (2003) Specificity assessment from fractionation experiments (SAFE): a novel method to evaluate microarray probe specificity based on hybridisation stringencies. Nucleic Acids Res 31, E1-1.

Dudoit, S., Shaffer, J.P. and Boldrick, J.C. (2003) Multiple Testing in Microarray Experiments. Statistical Science 18, 71-103.

Duplomb, L., Lee, Y., Wang, M.Y., Park, B.H., Takaishi, K., Agarwal, A.K. and Unger, R.H. (2004) Increased expression and activity of 11beta-HSD-1 in diabetic islets and prevention with troglitazone. Biochem Biophys Res Commun 313, 594-9.

Ghanaat-Pour, H., Huang, Z., Lehtihet, M. and Sjoholm, A. (2007) Global expression profiling of glucose-regulated genes in pancreatic islets of spontaneously diabetic Goto-Kakizaki rats. J Mol Endocrinol 39, 135-50. 
Hedge, P., Qi, R., Abernathy, K., Gay, C., Dharap, S., Gaspard, R., Hughes, J., Snesrud, E., Lee, E. and Quackenbush, J. (2000) A concise guide to cDNA microarray analysis. Biotechniques 29, 548-56.

Itoh, N. and Okamoto, H. (1980) Translational control of proinsulin synthesis by glucose. Nature 283, 100-2.

Jeong, I.K., Oh, S.H., Kim, B.J., Chung, J.H., Min, Y.K., Lee, M.S., Lee, M.K. and Kim, K.W. (2001) The effects of dexamethasone on insulin release and biosynthesis are dependent on the dose and duration of treatment. Diabetes Res Clin Pract 51, 163-71.

Johansson, U., Olsson, A., Gabrielsson, S., Nilsson, B. and Korsgren, O. (2003) Inflammatory mediators expressed in human islets of Langerhans: implications for islet transplantation. Biochem Biophys Res Commun 308, 474-9.

Karlsson, S., Ostlund, B., Myrsen-Axcrona, U., Sundler, F. and Ahren, B. (2001) Beta cell adaptation to dexamethasone-induced insulin resistance in rats involves increased glucose responsiveness but not glucose effectiveness. Pancreas 22, 148-56.

Kawai, A. and Kuzuya, N. (1974) [Proceedings: Stimulatory action of glucocorticoids on insulin secretion]. Nippon Naibunpi Gakkai Zasshi 50, 226.

Kawai, A. and Kuzuya, N. (1977) On the role of glucocorticoid in glucose-induced insulin secretion. Horm Metab Res 9, 361-5.

Khan, A., Ostenson, C.G., Berggren, P.O. and Efendic, S. (1992) Glucocorticoid increases glucose cycling and inhibits insulin release in pancreatic islets of ob/ob mice. Am J Physiol 263, E663-6.

Koizumi, M. and Yada, T. (2008) Sub-chronic stimulation of glucocorticoid receptor impairs and mineralocorticoid receptor protects cytosolic $\mathrm{Ca} 2+$ responses to glucose in pancreatic beta-cells. J Endocrinol 197, 221-9.

Lambillotte, C., Gilon, P. and Henquin, J.C. (1997) Direct glucocorticoid inhibition of insulin secretion. An in vitro study of dexamethasone effects in mouse islets. J Clin Invest 99, 414-23.

Lang, J. (1999) Molecular mechanisms and regulation of insulin exocytosis as a paradigm of endocrine secretion. Eur J Biochem 259, 3-17.

Leibiger, B., Moede, T., Schwarz, T., Brown, G.R., Kohler, M., Leibiger, I.B. and Berggren, P.O. (1998) Short-term regulation of insulin gene transcription by glucose. Proc Natl Acad Sci U S A 95, 9307-12.

Lenzen, S. and Bailey, C.J. (1984) Thyroid hormones, gonadal and adrenocortical steroids and the function of the islets of Langerhans. Endocr Rev 5, 411-34.

Oppermann, U. (2006) Type 111 beta-hydroxysteroid dehydrogenase as universal drug target in metabolic diseases? Endocr Metab Immune Disord Drug Targets 6, 259-69.

Oppermann, U.C., Persson, B. and Jornvall, H. (1997) Function, gene organization and protein structures of 11 beta-hydroxysteroid dehydrogenase isoforms. Eur $\mathbf{J}$ Biochem 249, 355-60.

Ortsater, H., Alberts, P., Warpman, U., Engblom, L.O., Abrahmsen, L. and Bergsten, P. (2005) Regulation of 11beta-hydroxysteroid dehydrogenase type 1 and glucose-stimulated insulin secretion in pancreatic islets of Langerhans. Diabetes Metab Res Rev 21, 359-66.

Stulnig, T.M., Oppermann, U., Steffensen, K.R., Schuster, G.U. and Gustafsson, J.A. (2002) Liver X receptors downregulate 11 beta-hydroxysteroid dehydrogenase type 1 expression and activity. Diabetes 51, 2426-33. 
Stulnig, T.M., Steffensen, K.R., Gao, H., Reimers, M., Dahlman-Wright, K., Schuster, G.U. and Gustafsson, J.A. (2002) Novel roles of liver X receptors exposed by gene expression profiling in liver and adipose tissue. Mol Pharmacol 62, 1299305.

Swali, A., Walker, E.A., Lavery, G.G., Tomlinson, J.W. and Stewart, P.M. (2008) 11 beta-Hydroxysteroid dehydrogenase type 1 regulates insulin and glucagon secretion in pancreatic islets. Diabetologia.

Tomlinson, J.W. and Stewart, P.M. (2007) Modulation of glucocorticoid action and the treatment of type-2 diabetes. Best Pract Res Clin Endocrinol Metab 21, 607-19.

Tseng, C.C. and Zhang, X.Y. (2000) Role of G protein-coupled receptor kinases in glucose-dependent insulinotropic polypeptide receptor signaling. Endocrinology 141, 947-52.

Walker, B.R. and Seckl, J.R. (2003) 11beta-Hydroxysteroid dehydrogenase Type 1 as a novel therapeutic target in metabolic and neurodegenerative disease. Expert Opin Ther Targets 7, 771-83.

Willi, S.M., Kennedy, A., Brant, B.P., Wallace, P., Rogers, N.L. and Garvey, W.T. (2002) Effective use of thiazolidinediones for the treatment of glucocorticoidinduced diabetes. Diabetes Res Clin Pract 58, 87-96.

Willi, S.M., Kennedy, A., Wallace, P., Ganaway, E., Rogers, N.L. and Garvey, W.T. (2002) Troglitazone antagonizes metabolic effects of glucocorticoids in humans: effects on glucose tolerance, insulin sensitivity, suppression of free fatty acids, and leptin. Diabetes 51, 2895-902.

Yang, Y.H., Dudoit, S., Luu, P., Lin, D.M., Peng, V., Ngai, J. and Speed, T.P. (2002) Normalization for cDNA microarray data: a robust composite method addressing single and multiple slide systematic variation. Nucleic Acids Res 30 , e15. 
Table 1: Primer pairs used for real-time quantitative PCR using SYBRgreen labeling.

\begin{tabular}{|c|c|c|}
\hline Gene & Sequences of forward and reverse primers ( $5^{\prime}$ to $3^{\prime}$ ) & $\begin{array}{l}\text { Source of sequence } \\
\text { data }\end{array}$ \\
\hline Rgs2 & $\begin{array}{l}\text { CGG CCC CAA GGT CGA } \\
\text { CAA ACG GGT CTT CCA ATC CTT }\end{array}$ & af_43291 \\
\hline Len2 & $\begin{array}{l}\text { CAA AAT TAC CCT GTA TGG AAG AAC C } \\
\text { ACA CTC ACC ACC CAT TCA GTT GT }\end{array}$ & nm_008491 \\
\hline Fkbp5 & $\begin{array}{l}\text { CAG GCT GCC ATC GTG AAA } \\
\text { TGC GTG TAC TTG GGT GGG TT }\end{array}$ & nm_010220 \\
\hline RNAse4 & $\begin{array}{l}\text { ATA TCG GGG TCG TGT TTC CA } \\
\text { ATC CAT CAT TAC CTA GAA AGT GCC T }\end{array}$ & nm_041472 \\
\hline Hspb1 & $\begin{array}{l}\text { CAA GGA AGG CGT GGT GGA } \\
\text { AGC CAT GTT CGT CCT GCC }\end{array}$ & nm_013560 \\
\hline Meth & $\begin{array}{l}\text { CAT ACA AAC GCT GAC GGA TGA } \\
\text { TCT GCC TTC TGT GCT TTC AGT TC }\end{array}$ & bc_052040 \\
\hline Itmap1 & $\begin{array}{l}\text { ACT TAA TCA GCA GCG GAT GTT GTT } \\
\text { CGA GAT GTT TGG TCA TTG TTA TCA C }\end{array}$ & nm_008411 \\
\hline$\overline{\text { Fabp4 }}$ & $\begin{array}{l}\text { GAA TTC GAT GAA ATC ACC GCA } \\
\text { CTC TTT ATT GTG GTC GAC TTT CC }\end{array}$ & nm_024406 \\
\hline $\mathrm{Pdx} 1$ & $\begin{array}{l}\text { CCT TTC CCG TGG ATG AAA TC } \\
\text { TCG GGT TCC GCT GTG TAA }\end{array}$ & nm_008814 \\
\hline $11 \beta$-HSD1 & $\begin{array}{l}\text { AAGCAGAGCAATGGCAGCAT } \\
\text { GAGCAATCATAGGCTGGGTCAT }\end{array}$ & $\mathrm{X} 83202$ \\
\hline Serpina12 & $\begin{array}{l}\text { GCA GGA GAG CTG GCT GTC A } \\
\text { GCA GGA GAG CTG GCT GTC A }\end{array}$ & nm_026535 \\
\hline
\end{tabular}


Table 2: List of the 100 most differentially expressed genes obtained by short-term corticosterone treatment of islets derived from lean C57BL/6J mice. $\mathrm{n}=5$ experiments. The table contains the following information 1) function, divided into main groups and subclasses, 2) Genbank ID, 3) gene name (underlined genes were further processed by RT QPCR, 4) log2-fold change, 5) p-values, adjusted using false discovery rate (p.fdr) (See (Dudoit et al., 2003) for an overview).

\begin{tabular}{|c|c|c|c|c|}
\hline Function & Genbank ID & name & $\begin{array}{l}\text { log2 fold } \\
\text { change }\end{array}$ & p.fdr \\
\hline \multicolumn{5}{|l|}{ Transport } \\
\hline & BC016584 & glycolipid transfer protein & -1.66 & 0.0921 \\
\hline \multicolumn{5}{|c|}{ Vesicle } \\
\hline & NM_008411 & integral membrane-associated protein 1 (Itmap1) & 2.35 & 0.0026 \\
\hline & NM_007694 & chromogranin B & -0.77 & 0.0921 \\
\hline & NM_026168 & PTX1 protein & 1.49 & 0.0921 \\
\hline \multicolumn{5}{|l|}{ Signal Transduction } \\
\hline & BB191620 & Ras-related GTP binding D & -1.46 & 0.0812 \\
\hline & AF432916 & $\underline{\text { Regulator of G-protein signaling } 2 \text { (Rgs2) }}$ & 2.01 & 0.0089 \\
\hline & NM_009061 & K0617F02-3 NIA & 1.61 & 0.0198 \\
\hline & NM_016693 & Mitogen-activated protein kinase kinase kinase 6 & 1.40 & 0.0448 \\
\hline & NM_181593 & inositol 1,4,5-trisphosphate 3-kinase C & 1.31 & 0.0862 \\
\hline & BB017040 & RIKEN BB017040 & -2.32 & 0.0921 \\
\hline & NM_023456 & Neuropeptide Y precursor & 1.26 & 0.0921 \\
\hline & BF136563 & Similar to KIAA1741 protein & 0.90 & 0.0921 \\
\hline & NM_010345 & growth factor receptor bound protein 1 & 0.91 & 0.1027 \\
\hline \multicolumn{5}{|c|}{ transcription factor } \\
\hline & BG965788 & transcription factor ETV6 & 1.11 & 0.0762 \\
\hline & NM_010638 & basic transcription element binding protein 1 & 1.00 & 0.0921 \\
\hline & NM_010330 & Embigin precursor & -0.96 & 0.0974 \\
\hline \multicolumn{5}{|c|}{ ion channel } \\
\hline & NM_009206 & adaptor protein kanadaptin & 1.09 & 0.1048 \\
\hline & NM_019664 & potassium inwardly-rectifying channel & 1.96 & 0.0069 \\
\hline & NM_007384 & amiloride-sensitive cation channel 1 & 0.85 & 0.0974 \\
\hline \multicolumn{5}{|l|}{$\underline{\text { Stress response }}$} \\
\hline & NM_013560 & heat shock protein 1 (hspb1) & 2.02 & 0.0089 \\
\hline & NM_012032 & membrane protein TMS-1 & 1.52 & 0.0974 \\
\hline & NM_031165 & heat shock protein 8 & 1.39 & 0.0762 \\
\hline \multicolumn{5}{|c|}{ inflammation } \\
\hline & ВC011437 & interleukin 1 beta & -2.47 & 0.0448 \\
\hline & NM_010492 & Islet cell autoantigen 1 & 2.73 & 0.0064 \\
\hline & NM_008013 & fibrinogen-like protein 2 & 0.97 & 0.0577 \\
\hline & NM_008491 & lipocalin precursor $(\operatorname{Lcn} 2)$ & 2.00 & 0.0089 \\
\hline & NM_011315 & $\overline{\text { Serum amyloid } \mathrm{A} 3}$ & 2.05 & 0.0806 \\
\hline & NM_009363 & Trefoil factor 2 precursor & -0.82 & 0.0974 \\
\hline & NM_010220 & $\underline{\text { FK506 binding protein } 5 \text { (Fkbp5) }}$ & 1.02 & 0.0398 \\
\hline & NM_010501 & Interferon-induced protein tetratricopeptide repeats 3 & -1.44 & 0.0188 \\
\hline \multicolumn{5}{|c|}{ extracellular matrix } \\
\hline & NM_146248 & a-helical protein & 1.17 & 0.0640 \\
\hline & NM_009930 & procollagen, type III, alpha 1 & 0.84 & 0.0809 \\
\hline & NM_008877 & Plasminogen precursor & -2.70 & 0.0843 \\
\hline & NM_007743 & Collagen alpha 2(I) chain precursor & 1.11 & 0.0921 \\
\hline$\nabla$ & NM_028072 & sulfatase 2 (Sulf2-pending) & 0.67 & 0.0921 \\
\hline \multicolumn{5}{|c|}{ Proteolytic processing } \\
\hline & NM_026535 & $\underline{\text { serine proteinase inhibitor (Serpina 12) }}$ & 2.89 & 0.0056 \\
\hline & M64085.1 & Contrapsin-like protease inhibitor (CPI-26) & 2.26 & 0.0064 \\
\hline & BI694738 & spi2 proteinase inhibitor & 2.19 & 0.0193 \\
\hline & BE851987 & Kallikrein-binding protein precursor (Serpina3g) & 1.42 & 0.0198 \\
\hline & NM_011458 & Contrapsin precursor (Serpina3k). & 2.44 & 0.0269 \\
\hline & NM_011595 & Metalloproteinase inhibitor 3 precursor & 2.96 & 0.0921 \\
\hline \multicolumn{5}{|c|}{ protein turnover } \\
\hline & NM_175340 & NHL repeat containing 1 & -1.75 & 0.0921 \\
\hline & NM_021301 & solute carrier family $15(\mathrm{H}+/$ peptide transporter) & -0.98 & 0.1027 \\
\hline & NM_010295 & Glutamate-cysteine ligase & 1.06 & 0.0577 \\
\hline
\end{tabular}


$\underline{\text { Metabolism }}$

\begin{tabular}{|c|c|c|c|c|}
\hline \multicolumn{5}{|l|}{ Metabolism } \\
\hline & NM_008898 & NADPH-cytochrome $\mathbf{P 4 5 0}$ reductase & 1.30 & 0.0089 \\
\hline & BC011202 & Selenium-binding protein 1 & 1.08 & 0.0357 \\
\hline \multicolumn{5}{|c|}{ protein metabolism } \\
\hline & ВC016492 & transglutaminase 2 & 0.67 & 0.1027 \\
\hline \multicolumn{5}{|c|}{ nucleotide metabolism } \\
\hline & BI713856 & alkaline phosphodiesterase & -2.29 & 0.0974 \\
\hline & NM_021472 & $\underline{\text { Ribonuclease } 4 \text { precursor (RNase4) }}$ & -1.27 & 0.0089 \\
\hline & BM196407 & Methionyl-tRNA synthetase (Meth, BM196407) & -1.11 & 0.0554 \\
\hline & NM_021335 & U2 small nuclear ribonucleoprotein B & -1.45 & 0.0921 \\
\hline & NM_011690 & valyl-tRNA synthetase 2 & 0.86 & 0.1027 \\
\hline \multicolumn{5}{|c|}{ transport } \\
\hline & NM_009155 & Selenoprotein P 1 & 1.41 & 0.0762 \\
\hline & NM_019414 & Selenium-binding protein 2 & 1.41 & 0.0772 \\
\hline & BC011202 & Mus musculus selenium binding protein 1 & 1.68 & 0.0974 \\
\hline \multicolumn{5}{|c|}{ lipid metabolism } \\
\hline & NM_024406 & Fatty acid-binding protein (Fabp4) & 1.21 & 0.0308 \\
\hline & NM_008509 & Lipoprotein lipase precursor & -1.31 & 0.0921 \\
\hline \multicolumn{5}{|c|}{$\underline{\text { miscellaneous }}$} \\
\hline & NM_011359 & Pulmonary surfactant-associated protein $\mathrm{C}$ precursor & 1.81 & 0.0997 \\
\hline \multicolumn{5}{|c|}{ growth factor } \\
\hline & NM_013655 & chemokine (C-X-C motif) ligand 12 & -1.71 & 0.0058 \\
\hline & NM_009264 & Small proline-rich protein $1 \mathrm{~A}$ & -2.37 & 0.0089 \\
\hline & NM_015776 & microfibrillar-associated protein 5 & 1.81 & 0.0762 \\
\hline & NM_008733 & nebulin-related anchoring protein & 1.98 & 0.0921 \\
\hline & NM_134471 & kinesin family member $2 \mathrm{C}$ & -1.94 & 0.1027 \\
\hline \multicolumn{5}{|c|}{ calcium binding } \\
\hline & NM_025994 & swiprosin 1. & 1.33 & 0.0261 \\
\hline & NM_022315 & SPARC related modular calcium binding 2 & 1.66 & 0.0772 \\
\hline \multicolumn{5}{|l|}{ unassigned } \\
\hline & AK013920 & RIKEN 3100002J23 & 1.13 & 0.0188 \\
\hline & NM_027727 & RIKEN cDNA 4933427L07 & -1.37 & 0.0193 \\
\hline & AA987153 & Sugano mouse kidney mkia & 1.92 & 0.0309 \\
\hline & AC125091 & BAC clone RP24-165P5 from chromosome 1 & 1.79 & 0.0357 \\
\hline & AV223084 & RIKEN 3830408C12 & 2.16 & 0.0398 \\
\hline & AC122337 & BAC clone RP23-351M10 from chromosome 12 & 2.08 & 0.0501 \\
\hline & NM_175329 & 16.7 Kd protein & -1.02 & 0.0577 \\
\hline & NM_153546 & O-acyltransferase (membrane bound) domain containing 1 & 0.98 & 0.0577 \\
\hline & BQ175097 & NIH_BMAP_DJ2 & 2.37 & 0.0586 \\
\hline & AI196943 & cryptochrome 2 & 0.85 & 0.0613 \\
\hline & BQ177102 & $\begin{array}{l}\text { UI-M-DJ2-bwa-j-15-0-UI.s1 NIH_BMAP_DJ2 Mus musculus } \\
\text { cDNA clone }\end{array}$ & 1.50 & 0.0709 \\
\hline & BC010768 & crystallin, alpha B & 0.82 & 0.0759 \\
\hline & AJ000262 & huntingtin associated protein 1 & -0.69 & 0.0762 \\
\hline & AL591544 & clone RP23-386D6 on chromosome 11 & 2.53 & 0.0812 \\
\hline & AF197878 & AF197878 Mus musculus C57BL/6J & 0.88 & 0.0812 \\
\hline & AW123290 & NIH_BMAP_M_S3.1 & -1.91 & 0.0836 \\
\hline & ВC028925 & Immunoglobulin kappa chain variable 1 (V1) & -1.76 & 0.0836 \\
\hline & NM_026293 & RIKEN 4930540L03 & -2.18 & 0.0843 \\
\hline & BI738207 & NIH_MGC_94 & 1.10 & 0.0872 \\
\hline & NM_027829 & RIKEN 9030607L17 & -2.27 & 0.0921 \\
\hline & BB199157 & RIKEN BB199157 & -1.81 & 0.0921 \\
\hline & AL837516 & clone RP23-234L8 on chromosome 2 & -1.65 & 0.0921 \\
\hline & NM_175533 & RIKEN 5830411N06 & -1.13 & 0.0921 \\
\hline & AA174873 & Soares mouse 3NbMS cDNA clone & 1.12 & 0.0921 \\
\hline & AI414870 & Soares mouse p3NMF19.5 cDNA clone & 1.25 & 0.0947 \\
\hline & AF291467 & HASH1 gene & -1.13 & 0.0974 \\
\hline & AV359767 & RIKEN AV359767 & -2.13 & 0.0990 \\
\hline & NM_009749 & brain expressed X-linked 2 & -0.77 & 0.1027 \\
\hline & AK019807.1 & RIKEN 4930572D21 & 2.34 & 0.1027 \\
\hline & BM219859 & C0931B05-3 NIA & 1.96 & 0.1027 \\
\hline & BC049975 & hypothetical protein LOC238393 & 1.47 & 0.1027 \\
\hline
\end{tabular}




\section{LEDGENDS TO FIGURES}

Figure 1: Corticosterone mediated amplification of glucose-stimulated insulin secretion. (A) Islets from lean mice were cultured for 18 hours in the absence or presence of $200 \mathrm{nM}$ corticosterone together or not with $1 \mu \mathrm{M}$ RU486. After culture, the islets secretory capacity was analyzed in perifusion experiments. Results show average insulin secretion (mean \pm SEM) for 17-25 separate experiments at 3 and 11 $\mathrm{mM}$ glucose. (B) Corticosterone effect on basal and the early and late phase of glucose-stimulated insulin secretion was examined over 2-120 hrs of glucocorticoid treatment. Data are presented as fold over control at the different time points.

Figure 2: $11 \beta$-HSD1 activity and GSIS in islet cultures derived from lean mice. Islets were cultivated for $18 \mathrm{hrs}$ with and without dehydrocorticosterone and analyzed as follows: (A) GSIS was 3.5-fold increased upon treatment with the inactive glucocorticoid dehydrocorticosterone, indicating glucocorticoid conversion by $11 \beta$ HSD1 in these islets. Insulin release in the presence of $11 \mathrm{mM}$ glucose in the absence (left bar) or presence of DHC (right bar) is presented as mean \pm SEM for 6 experiments. (B) Dehydrocorticosterone reductase activity in pancreatic islets is completely inhibited by the $11 \beta$-HSD inhibitor carbenoxolone. Data presented as mean \pm SEM for $n=3$ experiments for each treatment with 40 islets in each sample.

Figure 3: Scatter plot of p-value vs. estimated fold change for all features on the chip (volcano plot). The horizontal axis shows $\log 2$ of the observed mean of fold change; positive values correspond to overexpression in treated mice. The vertical axis shows - $\log 10$ of the p-value, comparing treated and untreated animals, adjusted for false discovery rate. The horizontal line is drawn at the traditional value of 0.05 , the vertical lines at -1 and 1 , corresponding to a two-fold change in mRNA. The labeled spots were chosen for QRT-PCR (see also Fig. 4).

Figure 4: Quantitative real-time PCR. Genes selected from functional classes showed high correlation (8/9) with the microarray results in differential expression patterns. Gene names as in Table 2. 
Figure 1
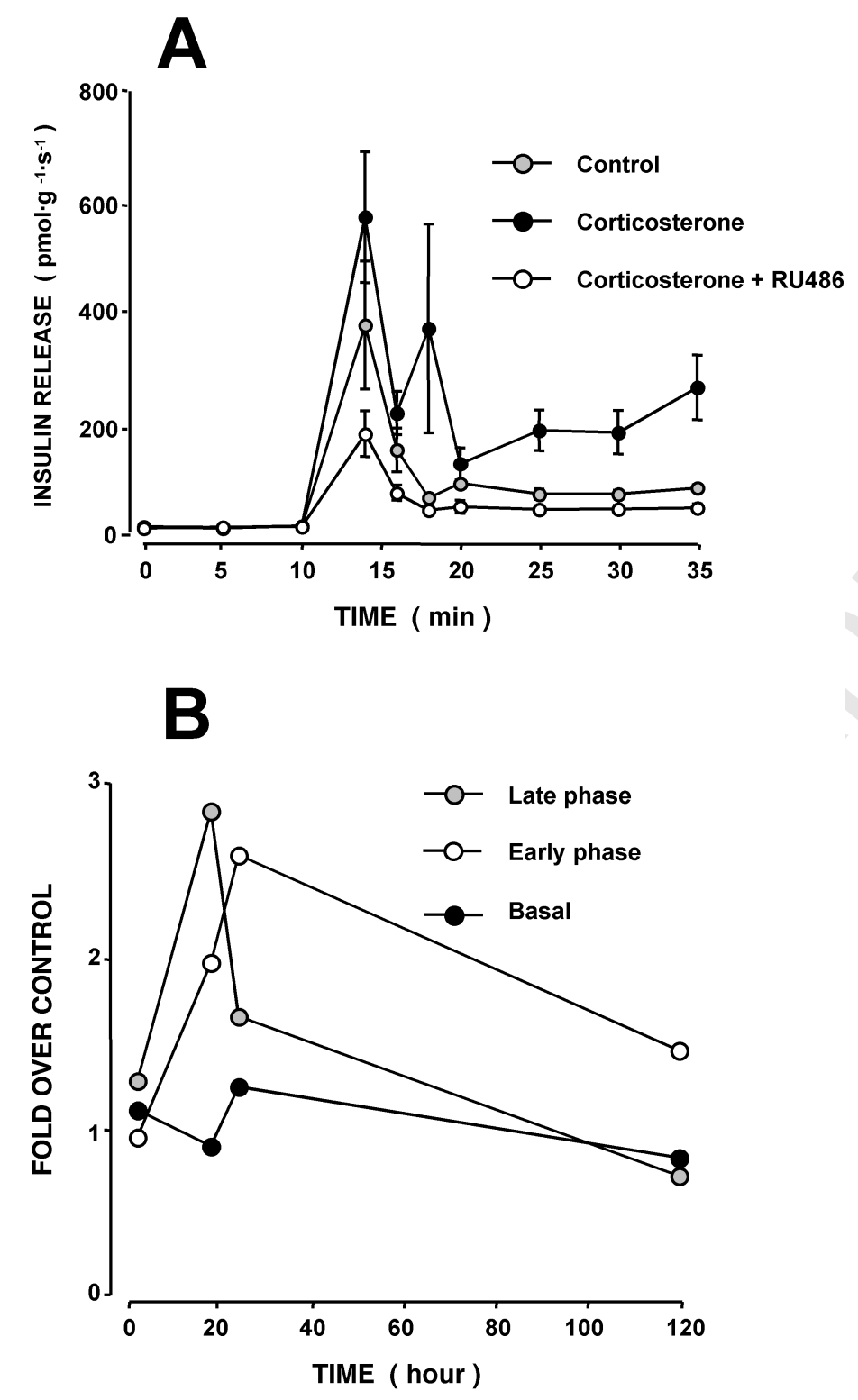
Figure 2

A

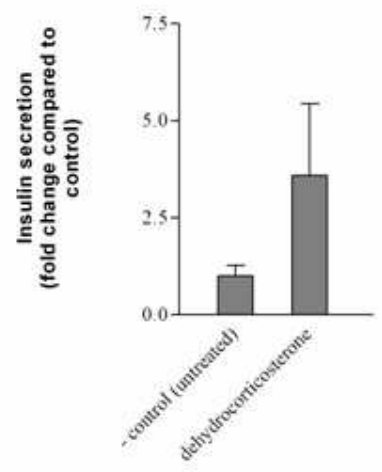

B

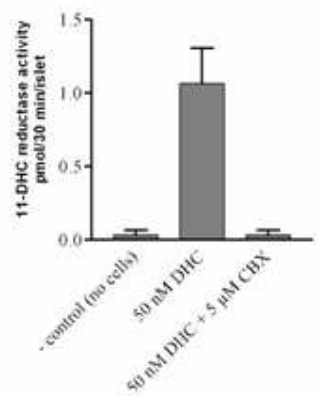


Figure 3

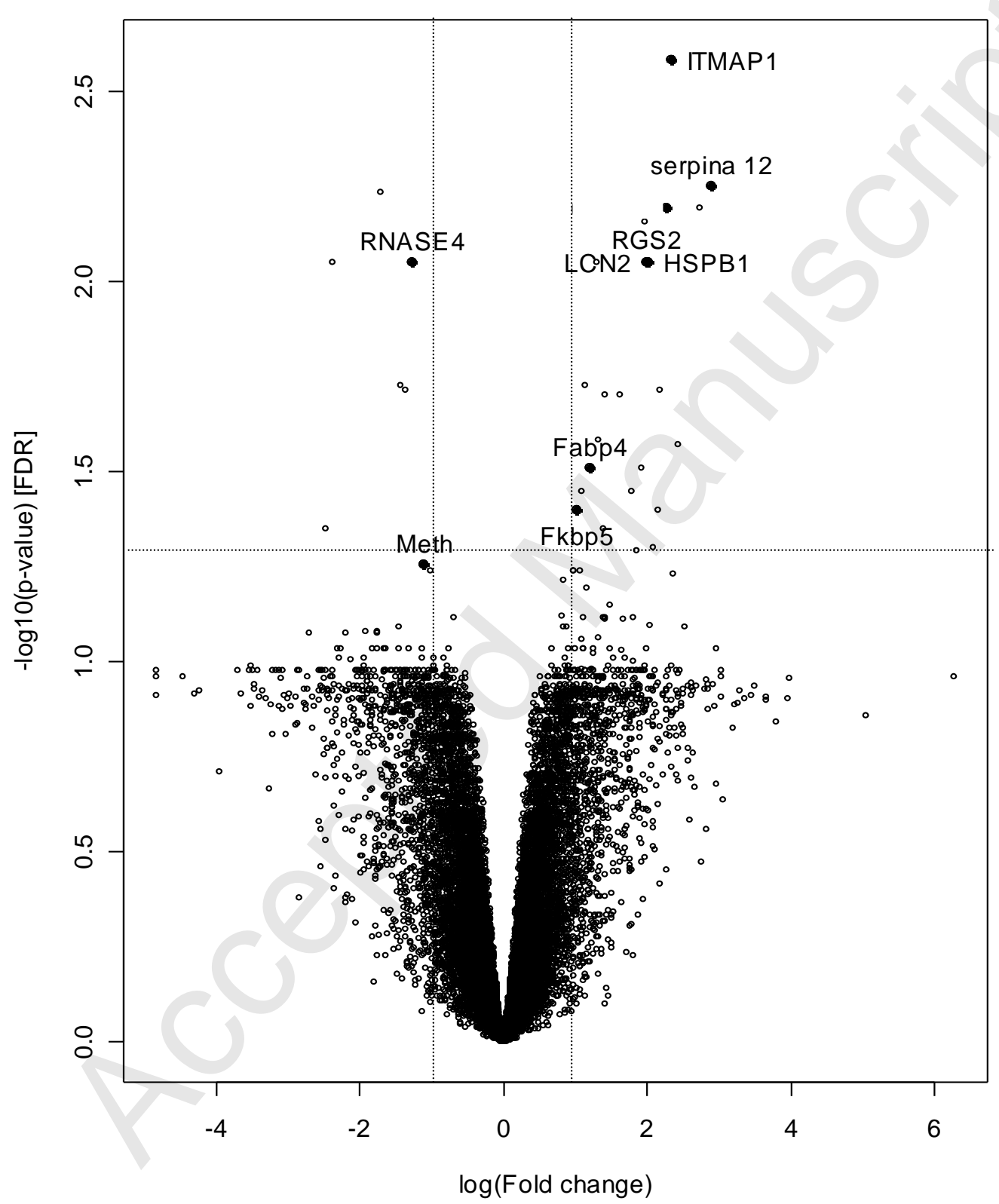


Figure 4.

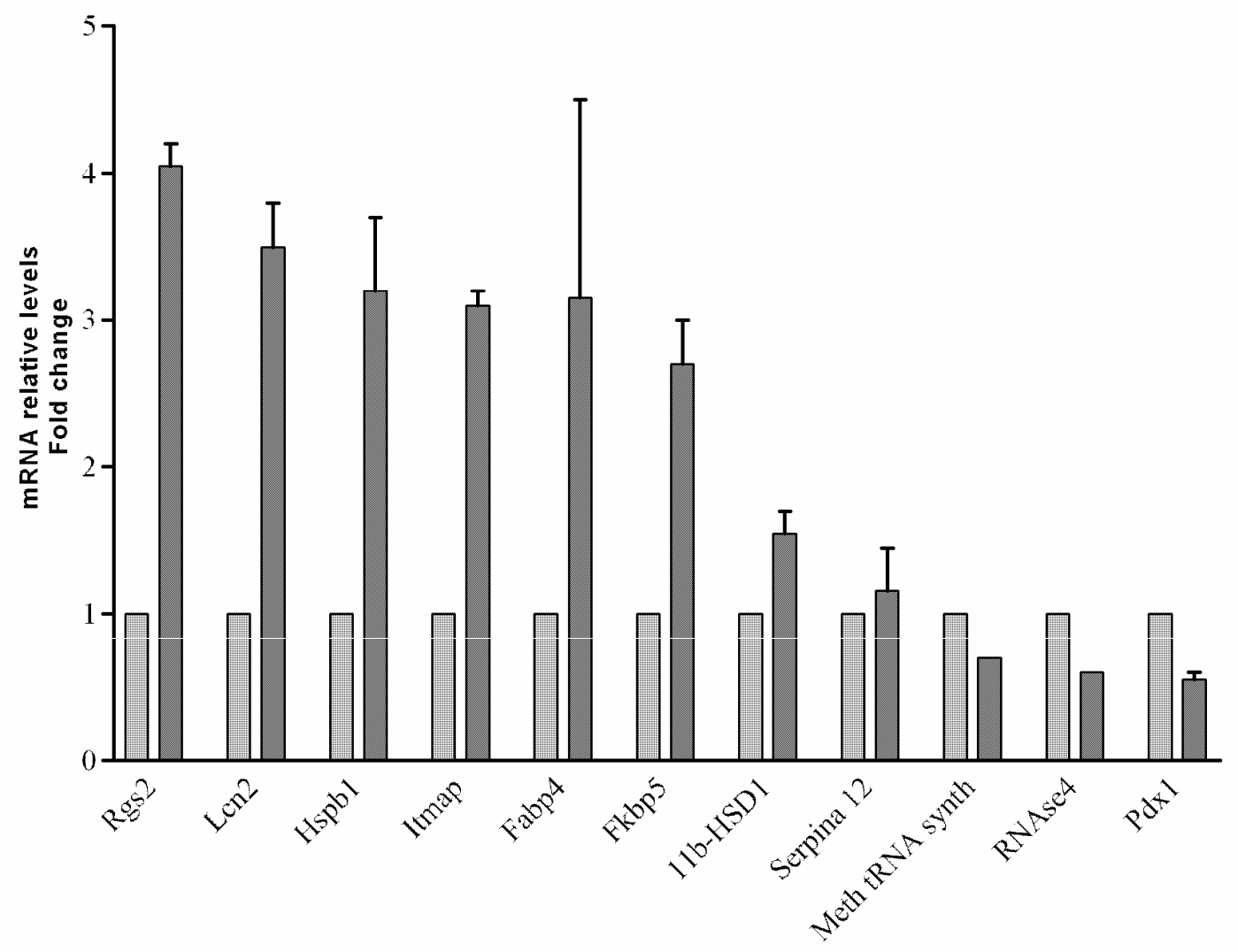

